\title{
Construction of Buckden's living stones rooms, Cambridgeshire, UK
}

Richard Noble MA Cantab, MICE, FIOCS

Retired civil engineer, ALM, St Mary's Church, Buckden, Diocese of Ely, UK

Faced with a set of daunting technical, conservation and budget challenges, in building a small extension onto a medieval church to serve the local community of Buckden, Cambridgeshire, UK, a group of retired civil engineers combined their experience to achieve a successful project outcome. Visitor and user facilities were squeezed into an extremely confined site, producing a development of exceptional quality. Using an innovative procurement route, the client formed its own limited company, directly employing the professional consultants on a design and build basis and taking on the project risks itself. Substantial savings were achieved by eliminating contractors' overhead costs and making extensive use of volunteer labour and expertise. The fact that the end user and contractor were the same people, having a deep understanding of client needs, helped in resolving a number of issues. These included the presence of ancient monuments, a diversity of interested parties and other complications. Work also included risk management, traditional external materials of stonework, lead and glazing for longevity, foundations of reinforced concrete ground slab and steel shell piles, temporary works, recycling and reuse of materials.

\section{Introduction}

Buckden is a busy village parish with a population approaching 3000 served by a number of shops, two hotels, a pub, three churches and a community centre. Situated in west Cambridgeshire, UK, $26 \mathrm{~km}$ north of Biggleswade on the north-south route of the A1 trunk road, Buckden has a long history both as a stopping-off point for travellers and, for many centuries when the diocese of Lincoln stretched from Oxford to the River Humber, a seat of Lincoln's bishops. Surviving from this background is a beautiful, grade 1 listed, medieval stone church, known as St Mary's, Buckden: the A1 church, and an adjacent Tudor brick keep, built by one of the bishops and part of Buckden Towers. These two buildings in their setting (Figures 1 and 2), together with remains of the Bishop's palace, form an attractive core to the village of historic and architectural importance. Through the last quarter of the twentieth century two growing needs were in opposition. On one hand, additional facilities, to serve the church and its many visitors - of toilets, running water kitchen and meeting rooms - and on the other, standing in the way of any development, the strictures of planning legislation to protect the legacies of history. Various schemes were put forward including both freestanding buildings and partitioning within the church interior, but each was faced by insuperable objections. The millennium provided the impetus for a fresh initiative, with a new architect commissioned to find a solution and an appeal in place to raise funds for a millennium bell and replacement bell frame as well as the future extension. The planning authority had stipulated that any new building should be invisible from the road and be externally indistinguishable from the existing building. This meant the only available site was in an area behind the church, bounded by a scheduled monument protected brick wall and occupied by some burial vaults, an oil storage tank and, in a narrow $3 \cdot 5-\mathrm{m}$ wide strip, a sub-ground boiler chamber and three massive brick buttresses (Figures 3 and 4).

\section{Project scheme}

After decades of discussion with conservation bodies and planners a realisable scheme was at last in place by 2004 and by the end of the year received full planning permission, scheduled ancient monument consent and an ecclesiastical faculty for the work. The proposed scheme consisted of two sections joined by a corridor. The church has a traditional layout of an arcaded fifteenth century central nave with a tower at the west end and the chancel at the east. North of the chancel is a nineteenth century addition of organ chamber and choir vestry. The facilities and a small meeting room were to be 'shoe-horned' into the narrow strip north of the nave (Figures 2, 3 and 5), accessed by opening up an old doorway once used by the bishops as the entrance from their palace. The Victorian vestry would be demolished to create space for a larger meeting room and an independent entrance to the new extension. Stones and dressed stonework from the vestry would be reused to build the west wall of the new extension, forming an exit doorway and window to complete a west-facing aspect to blend fully with the 
Construction of Buckden's

living stones rooms,

Cambridgeshire, UK

Noble

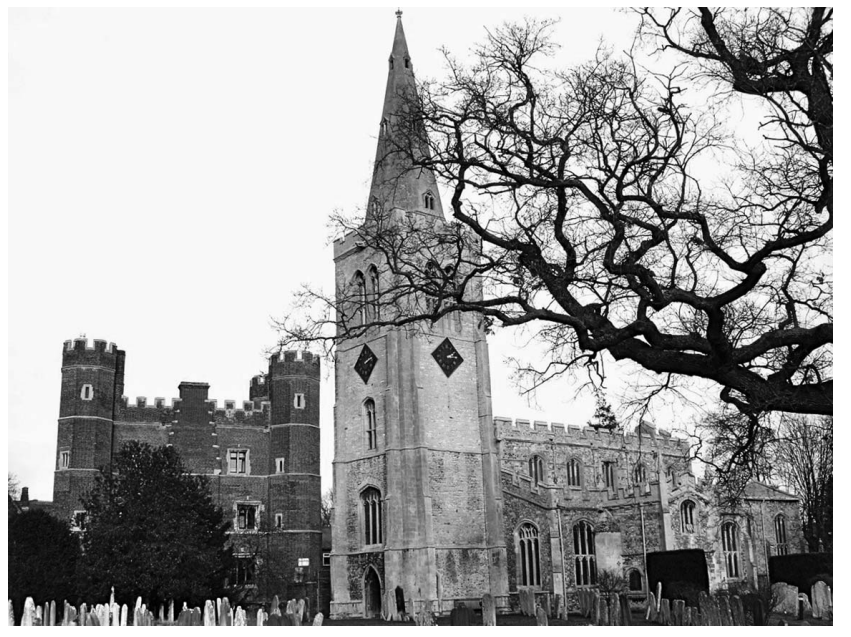

Figure 1. View of St Mary's Church, Buckden, with the Tudor brick keep of Buckden Towers

rest of the medieval building. A requirement of English Heritage was that the north wall of the organ chamber be dismantled stone by stone and rebuilt $2 \mathrm{~m}$ to the north to accommodate the corridor joining the two new sections. The preliminary project costings amounted to $£ 575000$ for some $150 \mathrm{~m}^{2}$ of additional floor space. This far exceeded the envisaged sources of funding, but undaunted by this prospect and to prevent inflation eroding the funds already raised the parochial church council (PCC) decided to start work on the first section of work that would provide toilets, kitchen and meeting space as soon as sufficient funds became available. Also on a suggestion from the architect, the possibilities were investigated for carrying out the proposed project on a design and build basis through a limited company formed for the purpose.

\section{Contractual arrangements}

The church congregation was fortunate in having among its number several retired civil engineers and others with construction experience. This made possible an innovative approach by the PCC through which it would itself take on the combined role of client and builder. To achieve this it set up a company limited by shares and registered for value added tax (VAT) to act as managing contractor, with suitably qualified members of the congregation as its directors. This company, Buckden's Living Stones (Construction) Ltd (BLSC) would employ the architect and other consultants directly, as well as all the specialists and tradesmen, directly purchasing all materials and supplies. Under this arrangement the PCC as building client, unusually, took upon itself the project risks instead of passing these to a main contractor, while insulating itself from legal liabilities or the possible failure of BLSC. This key decision would enable the following very considerable savings on project costs

no cost allowance for risk, normally built into a contractor's quotation

extension of existing church insurances to cover contractor's 'all risks'

minimal site preliminaries

no builder's overheads

- recovery of VAT on consultant's fees

employment of unpaid volunteers from the congregation

suspension of work during inclement weather free of cost

progress at speeds appropriate to expert craftwork free of extended overheads

delays for late or unavailable resources free of cost

additional time to resolve unexpected problems free from contractual claims

use of volunteers from the church community to clean for reuse, bricks and stones from the old buttresses and vestry.

After a programme of preparatory work the construction on the first phase of the extension began during the summer of 2006, much of it being carried out on a do-it-yourself basis.

\section{Preparatory work}

Before construction work could begin a number of physical obstacles had to be overcome. There was no available road access to the site and very little room to work between the boundary wall and the buttresses. The grave vaults and memorials also needed to be relocated or covered over. These alone indicate the scale of difficulties that faced the team from the outset. The only piece of good news followed a visit from the archaeologists who, having dug trenches and carried out their investigations, said they had no further interest in the site. Obtaining permissions for a site access was another matter altogether, with tree roots to be preserved, vicarage land to be occupied and access to the highway to be negotiated.

Even after reducing the extent of the massive buttresses there was only room on the construction site itself for barrow runs and the components of a tripod for piling. A further obstacle was the poor state of the boundary wall (Figure 3), which, being owned by the adjacent site and in the vicinity of a scheduled monument, needed the necessary consents. This wall would form the outside of the building extension envelope but was not to be interfered with. The architect needed to keep it separated from the new building except for weatherproofing at the top, and the structural engineer was commissioned to design a kentledge scaffold to support the wall, standing in the neighbouring property. An important consideration was health and safety and the need for BLSC to establish a compliant site compound. With the work being let in small packages and much of it being carried out by volunteers, risk assessments 


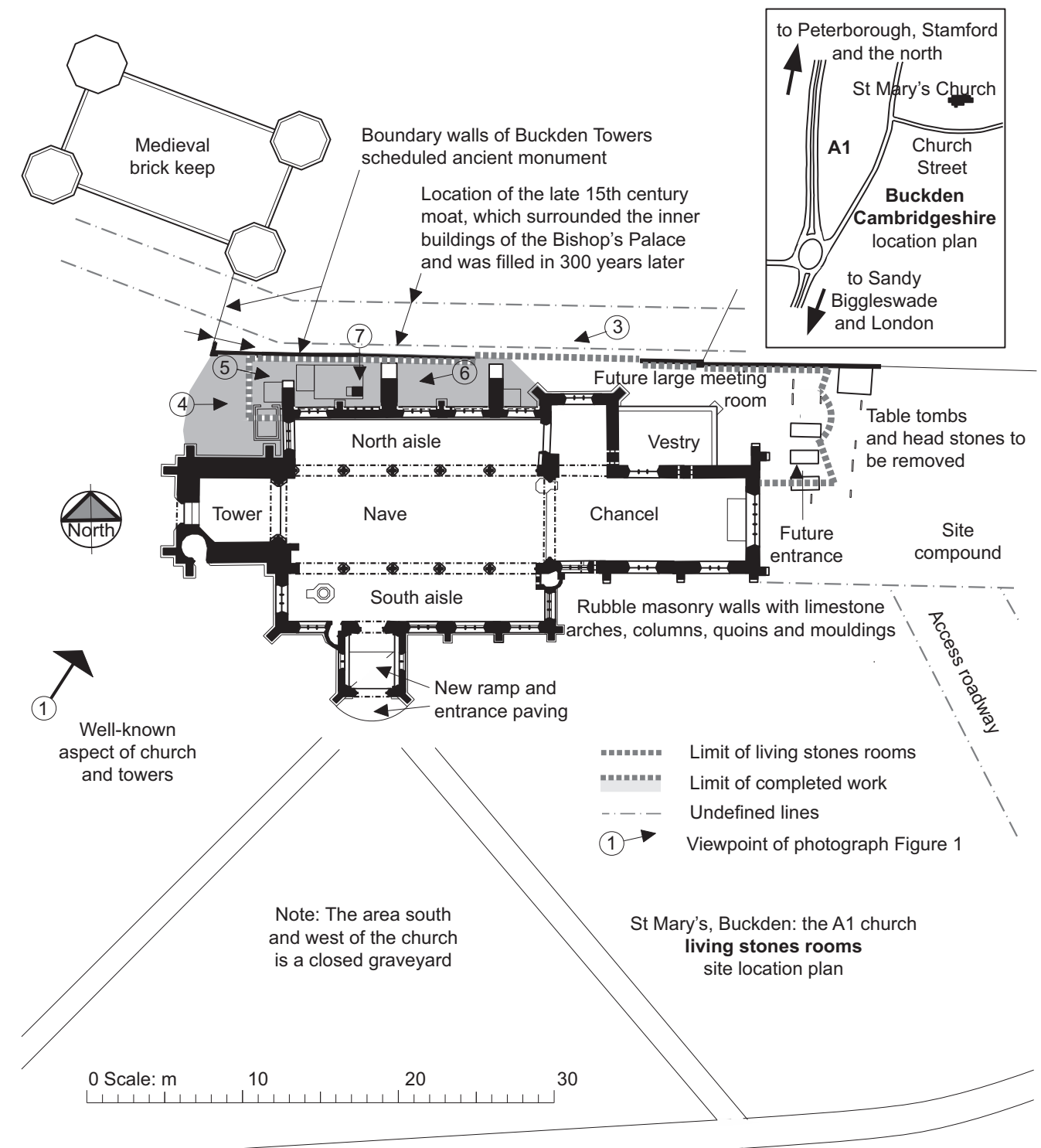

Church Street, Buckden

Figure 2. Location of St Mary's Church, Buckden, showing viewpoints of photographs in Figures 1 and 3-7

and detailed method statements were a feature throughout. A tribute to the degree of teamwork is the fact there was not a single lost time accident during 6 years of working.

\section{The buttresses}

A particular issue from the outset was the external wall of the existing medieval north aisle, which was to become an inside wall of the new accommodation. This wall was leaning outwards, and huge brick buttresses had been built against it, formed mainly of bricks from the eighteenth century or earlier. Measurements of the lean ranged between 200 and $300 \mathrm{~mm}$ over the $5.5 \mathrm{~m}$ height of the wall. The buttresses occupied the narrow space that was going to be utilised by the new facilities and would have to be demolished (Figure 5). An aspect of the 
Construction of Buckden's

living stones rooms,

Cambridgeshire, UK

Noble

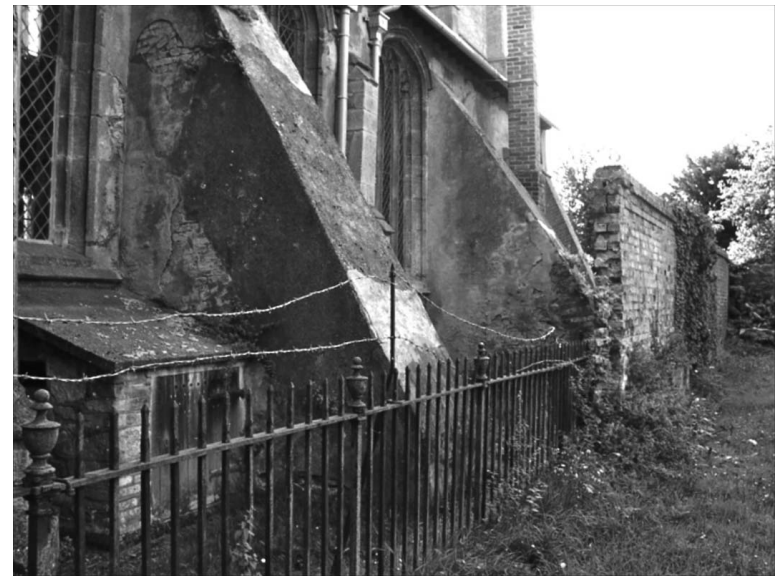

Figure 3. View from Buckden Towers grounds showing the boundary wall and massive buttresses filling the available site

architect's initial proposal was an array of flying buttresses, which would transfer the transverse loads from the wall into the new building structure. These would be a distinct visual
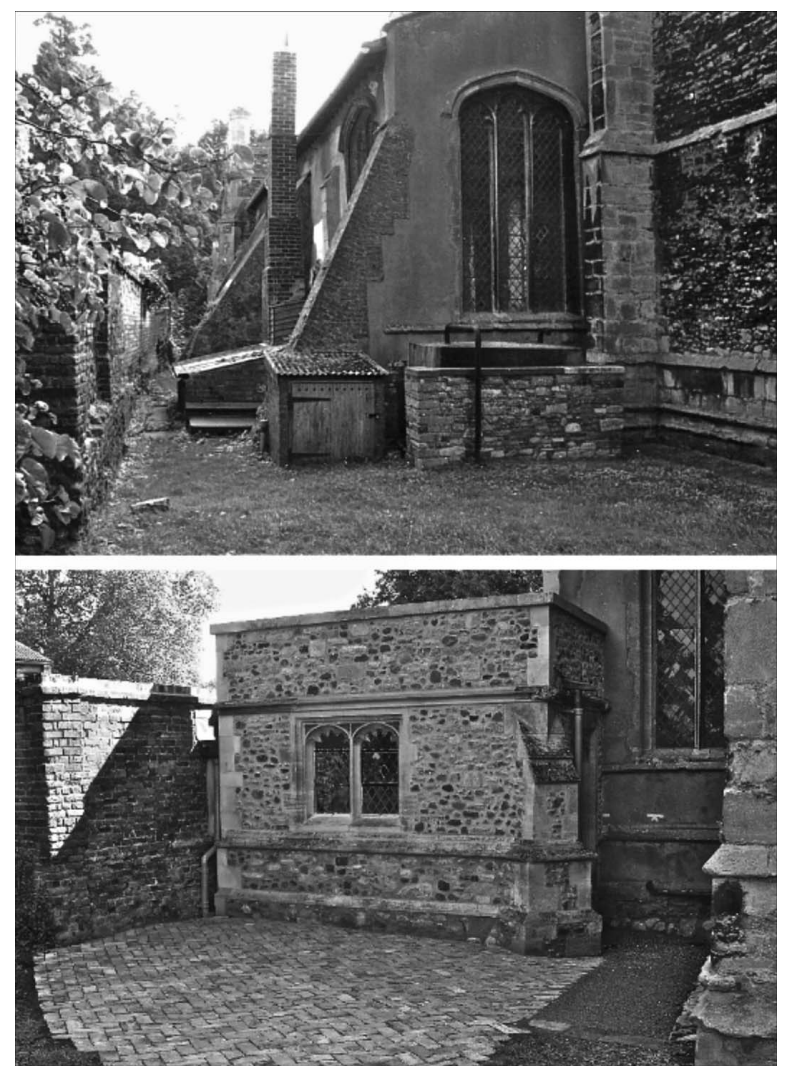

Figure 4. Before and after views showing boundary wall, buttresses, top of boiler chamber and oil storage tank replaced by new west wall and brick paving

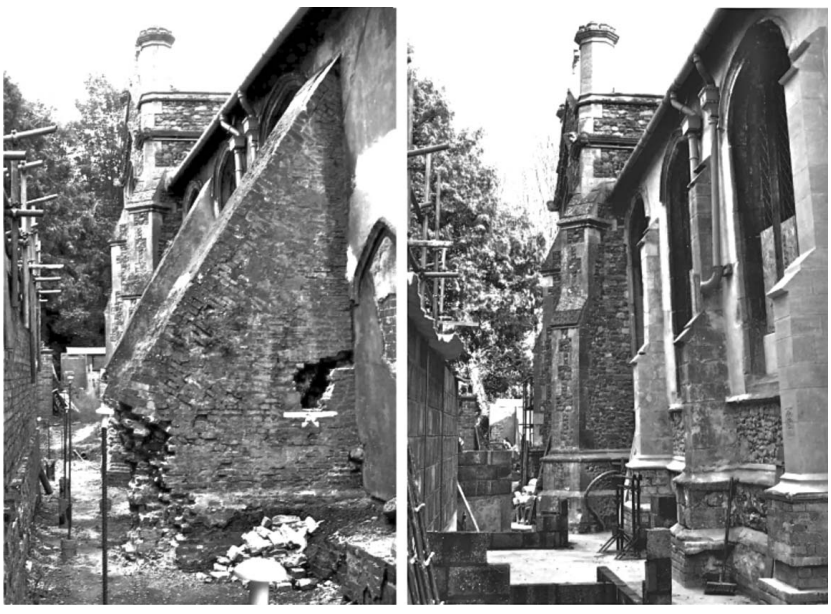

Figure 5. Before and after views showing the massive buttresses reduced for barrow access and later replaced by slender ones

feature of the design as well as being a witness to the leaning medieval church wall, but preliminary costings indicated they would come at a high price. The structural engineer was asked to find a less costly way of providing the necessary support. Careful examination of the existing structure indicated that the massive buttresses had settled under their own weight and no longer seemed to be providing support to the wall. Furthermore, the stonework, which had been stripped of plaster a century earlier, indicated that the movement of the wall was ancient. Thus it appeared to be self-supporting, with the buttresses already redundant. Examination of antique prints and old plans indicated that when the north wall was built, there was a moat running adjacent to the existing boundary wall (Figures 2 and 3), which had subsequently been filled in during the eighteenth century. The structural engineer was able to demonstrate to the architect that the wall would be stable if the massive buttresses were replaced with slender ones matching those still in place. To provide a secure base he proposed that the new slender buttresses be supported using a piled reinforced concrete (RC) raft as the floor slab of the new extension. This solution eliminated the costly flying buttresses as well as the need for transverse walls in the new building to take their loadings. The architect agreed, with some reluctance, to abandon his design concept of flying buttresses, allowing a more straightforward scheme and a considerable saving in cost.

\section{The leaning north wall of the church}

It needs to be appreciated as part of this situation that the concept of structural foundations was unknown in medieval times. Stone walls were usually simply founded on large stones placed directly on the ground after the removal of topsoil (Maxwell, 2008). At most a shallow trench might first be filled 
Construction of Buckden's

living stones rooms,

Cambridgeshire, UK

Noble with compacted earth and rubble. Walls were built over many months and even years, with the soil beneath them being slowly compacted with the growing weight of the rubble-filled masonry above. In this case injection grouting was considered as a way of stabilising the soil beneath the proposed ground slab while avoiding disturbance to the church building. Investigation revealed the area to be filled ground with brick fragments obstructing the auger. This determined the choice of $150 \mathrm{~mm}$ toe-driven, concrete-filled steel shell piles, in preference to grouting or mini auger piles. Three of the civil engineers in the construction team were involved in these deliberations with the structural engineer and architect, which continued with devising a sequence of work for forming the $\mathrm{RC}$ slab in sections during the sequential propping of the wall, dismantling of the massive buttresses and replacement with slender ones (Figure 5). A local site investigation specialist at favourable cost carried out an extensive range of trial bore holes. This confirmed the expected mixture of clay and gravel in the undisturbed strata. The quality of these subsoil data enabled keen quotations for the 6-7 $\mathrm{m}$ deep piling. As a precaution, inclinometers were bolted to the internal face of the walls at each buttress position to measure movements, with controls positioned against the church tower and an interior arcade column, where no movement was anticipated. Despite consternation when some hassocks bounced off the pews inside the church, movements of only a millimetre or two were indicated and even these were cyclical, being related to temperature or humidity rather than disturbance. After demolition of the massive buttresses, excavation to reduced levels and transfer of loads from the new buttresses to the new ground slab, the recorded data from the inclinometers indicated, if anything, a slight recovery in the verticality of the wall.

Three discoveries were made while the buttresses were being taken down. The first was hollows within the brickwork, some containing pieces of timber and wrought iron cramps, the second was remains of the original slender buttresses but these were largely missing in one case, and third, most of the bricks were rough paviors dating from the eighteenth century or earlier. The evidence supports the likely structural history that movement of the wall occurred early in its history, temporary support being provided by timber shores, these eventually becoming permanent and encased in brickwork. The proximity of the moat and likely seepage of water into the mixture of clay and gravel might have caused the wall's rotation. Another suggestion has been that the rotation could have occurred when the adjacent moat was filled in, the small reversal measured in tilt being explained by the removal of buttresses and overburden. The tilts measured by the inclinometers during 15 months of roofing and fitting out varied within a range of only $1.5 \mathrm{~mm}$, with a tendency to reduce further, and it was decided that the monitoring could be withdrawn. There have been no signs of any further movement and the structure will be monitored during the architect's routine 5-yearly inspections.

\section{Construction}

With the availability of cash depending on fundraising activities, and site constraints dictating the amount of simultaneous working, much more work was carried out by volunteers than had at first been envisaged. This extended the construction period by several years but had the dual advantages of involving the local community and saving a large sum of money. In many cases local expertise was offered at no cost or favourable rates, and specialist contractors tended to enter the spirit of the enterprise, generously resolving unforeseen difficulties without additional charge. Elements of work completed by volunteer labour included
- site preparation
construction of access driveway
- surveys and setting out
- hand digging for reduced levels and drainage runs
sub-ground pipe and ductwork
demolition and dismantling of existing fabric
- RC blinding, steel fixing, shuttering and concrete placing
- structural propping of north wall
manhandling and placing of structural steelwork
- timber superstructure carcassing
roof insulation between rafters and boarding out
final fitting out.

In addition to those previously described, particular challenges included: manhandling precast concrete manhole rings using lifting tackle into soak-away pits; arranging for concrete to be pumped over the church to form the RC ground slab; contriving the sequence of work to form large enough sections of RC slab from which to mount the steel props to support the church wall (Figure 6) while omitting sections of slab until buttresses were demolished; and forming the access doorway in the north wall of the church. This had been bricked up in an earlier century and contained the remains of a furnace flue. Above the doorway, inside the church, a large and ancient marble memorial had been taken down some years previously for maintenance and re-erected at a sufficient height for future door access. An additional challenge was the discovery that no provision had been made within the wall to support the marble memorial after opening up the doorway (Figure 7). This was already complicated by being over $100 \mathrm{~mm}$ out of plumb and all dimensions were critical. It required the combined ingenuity of the professional consultants, the volunteer experts, the steel fabricator and the stonemason to work out a composite structural support arrangement that could resist torsional forces, be built and welded progressively within the structure and yet reveal no sign of its presence after completion. A further complication was soot and heat damage to the stone 
Construction of Buckden's

living stones rooms,

Cambridgeshire, UK

Noble

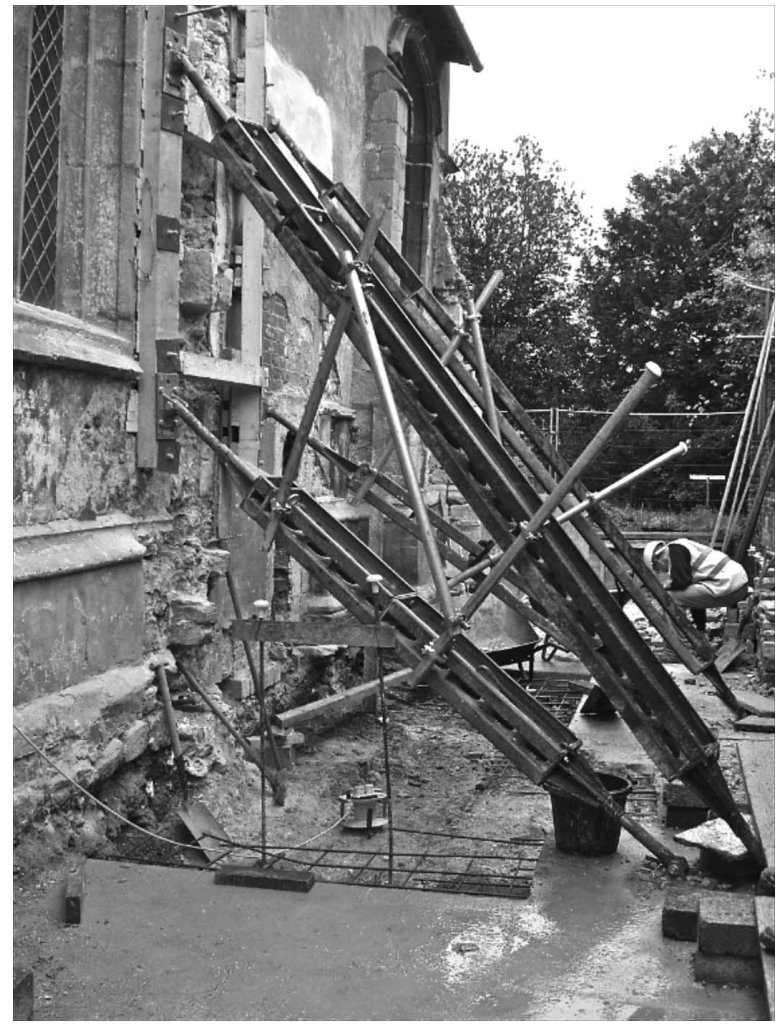

Figure 6. View showing props in place and buttress demolished, with RC slab and slender buttress above still to be completed (with retired volunteer civil engineer in background)

reveal moulding by the former furnace flue. When the stonemason, followed by conservation experts, failed to remove this using their specialist equipment, it was left to the volunteer experts to devise a method, using a do-it-yourself mini-needle tool hand drill attachment, to achieve a solution that was acceptable from a conservation perspective (Figure 7).

Work carried out by specialist contractors and tradesmen included

- site investigation and piling

relocation of burial monuments

- pumped delivery of flowing, self-compacting concrete

stonemasonry and inscription carving

brickwork and blockwork

timber joinery

- steelwork fabrication

- electrical installation

underfloor heating installation

rendering and internal plastering

plumbing

flooring and carpeting
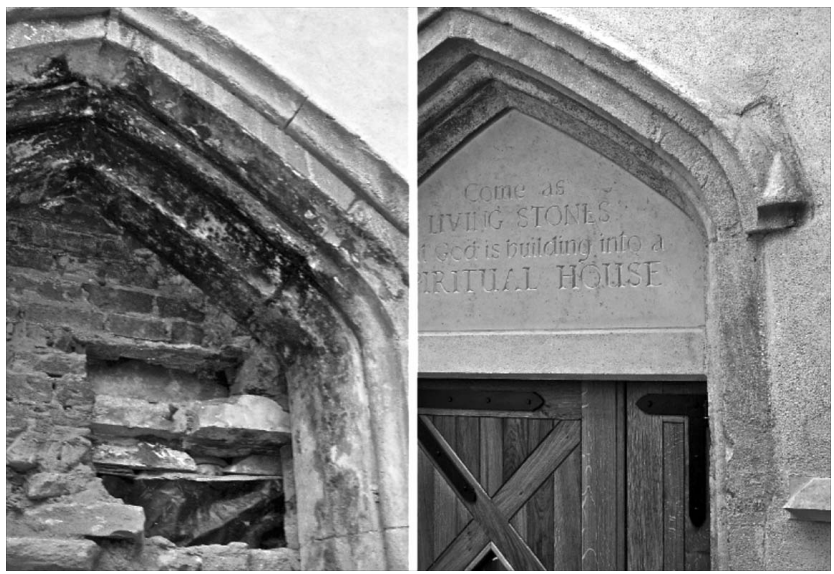

Figure 7. Before and after views showing doorway brickwork partly removed, revealing the back of the marble memorial and lack of provision for support, and the inscribed panel above the door

roof leadwork including reinstatement after destructive theft glazing

security installation against lead theft.

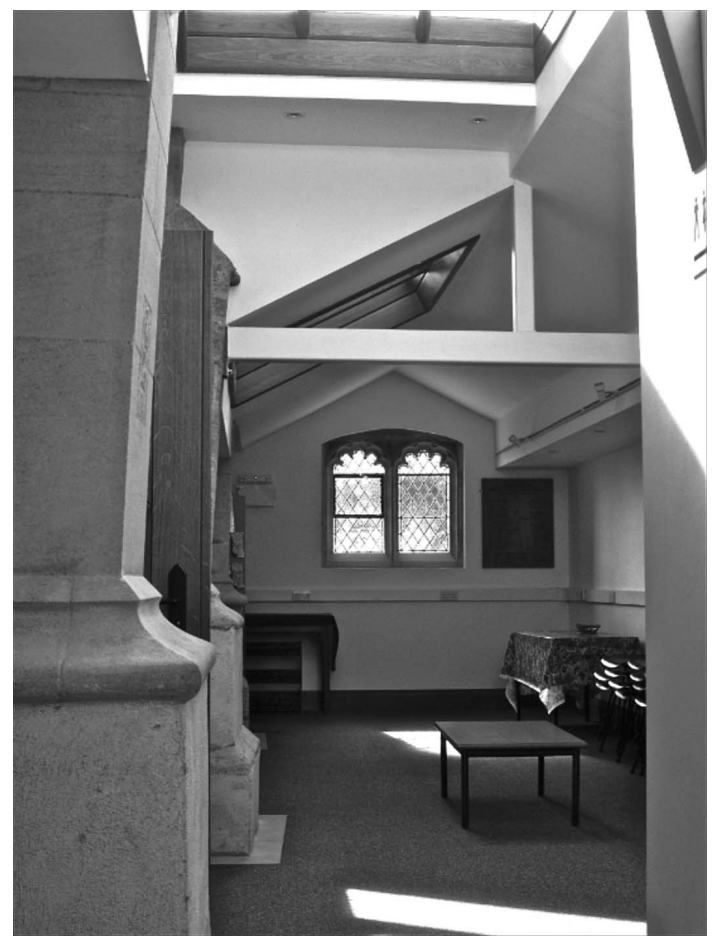

Figure 8. View from inside the meeting area of the living stones rooms, showing the light flooding into what had previously been a wasteland 
Municipal Engineer

Volume 167 Issue ME4
Construction of Buckden's

living stones rooms,

Cambridgeshire, UK

Noble
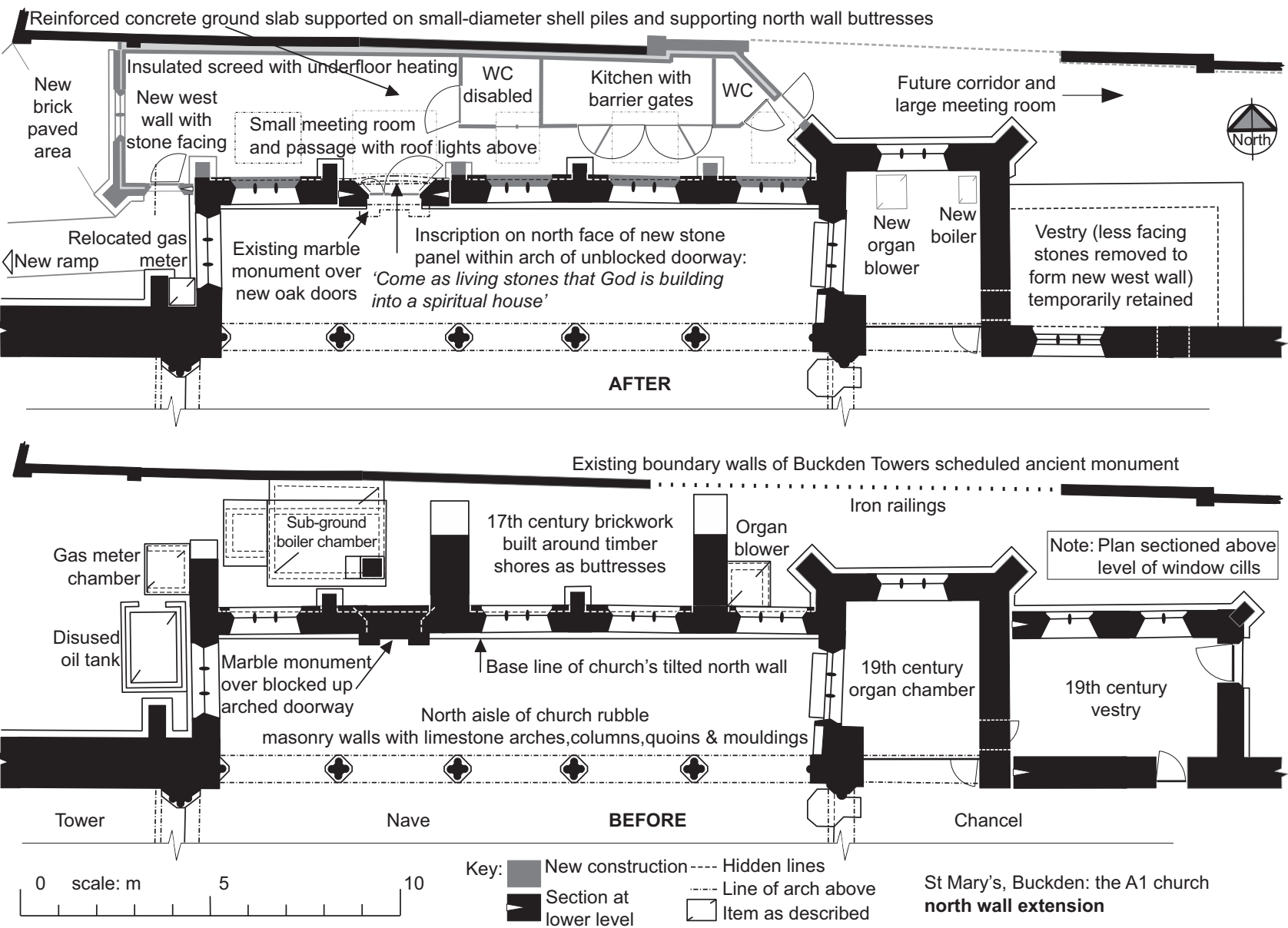

Figure 9. Before and after drawings showing the extent of the works

No critical path situations were met until after dates had been set for completion and opening celebrations on 24 September 2011. As the end approached, the firm contracted to supply and fit out the kitchen needed in time for the celebrations reneged on their agreed dates. A local builder who had offered helpful advice throughout the work came to the rescue, volunteering his own supplier to provide units at short notice, and one of the retired engineers stepped into the breach to fit out the kitchen, working alongside the services tradesmen with a further saving of several thousand pounds. This finishing touch underlined the whole spirit of the enterprise, but there was one more to come. At the opening ceremony one of the churchwardens remarked on how nice it would be to have a hard surface patio outside the doorway at the west end of the new extension. Remembering the antique paving bricks, salvaged from the buttresses and cleaned up by a group of women from the congregation, another gang of volunteers was soon recruited to lay an attractive herringbone brick-paved area that complements perfectly the reclaimed west elevation stonework (Figure 4).

The construction cost estimate for the development had been $£ 575000$ (current rates similar) of which a larger meeting room and vestibule still to be built as a second phase represents approximately $£ 175000$ at current rates. The total design and build cost of the $54 \mathrm{~m}^{2}$ of floor space, occupied by a small kitchen, two toilets and a meeting space, was a little under $£ 300000$. Thus a saving of around $£ 100000$ was realised, representing $20 \%$ on the development as a whole and $25 \%$ on this first phase. The result, with the architect's solution squeezing such useful accommodation into such a restricted space, has been universally acclaimed (Figure 8).

\section{Conclusions}

A development of exceptional quality has been built, both to serve the community and as an addition to the national 
heritage (Figure 9). A grade I listed medieval church building has been enhanced by modern facilities, built to high standards using traditional, long-lasting external materials. Due to an extremely constricted site and a number of daunting challenges the project had been considered very risky both technically and logistically. By adopting the innovative procurement approach of taking on the project risks itself and forming its own company to undertake the work, the client has been able to meet all the challenges while achieving substantial savings in cost and involving the local community. The fact that the end user and contractor were the same people, having a deep understanding of client needs, proved to be a key factor in resolving construction interface issues, both with the surrounding listed structures and between the large number of participants in the project. The unusual challenges required innovative approaches, without precedents to draw upon and with solutions only possible through the resourcefulness of experienced engineers. Three regional awards made in 2012, one from the Institution of Civil Engineers for physical achievement (Miles, 2012a), and two from Constructing Excellence, for value and heritage (Miles, 2012b), have recognised the success of the project.

Thanks are due to the parochial church council of St Mary's Church, Buckden, for permitting this project to be published and to the many participants who made it a reality.

\section{Project team}

David Joy MA, Dip Arch (Cantab), RIBA, Architect, JGP Architects, Cambridge, UK; Paul Riddington BSc(Eng), CEng, MICE, Engineer, P. \& T. Riddington Ltd, Cambridge, UK; Robert Shepard MCIOB retired, Planning supervisor, Fieldhouse (UK) Ltd; Barry Priest, Project chairman, volunteer retired; Peter Brittain MICE, Construction director, volunteer retired civil engineer; Robin Gibson MICE, Safety director, volunteer retired civil engineer; Richard Noble, MA Cantab, MICE, FIOCS, Consultant, volunteer retired civil engineer.

\section{REFERENCES}

Maxwell I (2008) Foundations and wall footings - technical information for historic building owners, Conservation, Historic Scotland. See http://www.historic-scotland.gov. uk/inform-foundation-and-walls.pdf (accessed 05/11/ 2013).

Miles P (2012a) Buckden Living Stones Development. ICE 2012 Merit Award submission, physical achievement category. Institution of Civil Engineers, London, UK.

Miles P (2012b) Buckden Living Stones Development.

Constructing Excellence 2012 East of England Regional Awards submissions, heritage and value categories. Constructing Excellence, London, UK.

\footnotetext{
WHAT DO YOU THINK?

To discuss this paper, please email up to 500 words to the editor at journals@ice.org.uk. Your contribution will be forwarded to the author(s) for a reply and, if considered appropriate by the editorial panel, will be published as discussion in a future issue of the journal.

Proceedings journals rely entirely on contributions sent in by civil engineering professionals, academics and students. Papers should be 2000-5000 words long (briefing papers should be 1000-2000 words long), with adequate illustrations and references. You can submit your paper online via www.icevirtuallibrary.com/content/journals, where you will also find detailed author guidelines.
} 